\title{
Immunohistochemical Analysis of Placental Microvessel Density and Spiral Artery Doppler Results in Preeclamptic Pregnancies
}

\author{
Bahar Ergen,, (1) Kadir Güzelmeriç,, (1) Gülden Yılmazer,' (1) Cenk Ergen, ${ }^{2}$

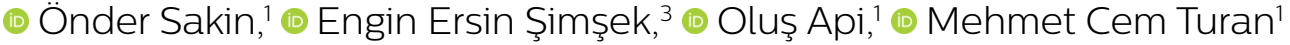

\begin{abstract}
'Department of Obstetrics and Gynecology, Kartal Dr. Lütfi Kırdar

Training and Research Hospital, İstanbul, Turkey

${ }^{2}$ Department of Pathology, Kartal Dr. Lütfi Kırdar Training and Research Hospital, İstanbul, Turkey ${ }^{3}$ Department of Family Medicine, Kartal Dr. Lütfi Kırdar Training and Research Hospital, İstanbul, Turkey
\end{abstract}

Submitted: 07.04.2018 Accepted: 03.07.2018

Correspondence: Önder Sakin, Dr Lütfi Kırdar Kartal Eğitim ve Araştırma Hastanesi Kadın Hastalıkları ve Doğum Kliniği, İstanbul, Turkey

E-mail: sakin-onder@hotmail.com

口isto

Keywords: Antigen CD34; microvessels; preeclampsia; ultrasonography Doppler.

\begin{abstract}
Objective: To investigate placental immunohistochemical findings and Doppler parameters in normal pregnancies and women with preeclampsia (PE).
\end{abstract}

Methods: Doppler measurements of umbilical, uterine, and spiral arteries of 23 PE and I2 normal pregnancies followed and delivered between 2008 and 2010 were performed and recorded. Placental specimens were obtained at birth and the microvessel density of spiral arteries was measured immunohistochemically using placental tissue CD 34 antibody expression. Three vessels with the most intense CD34 density were evaluated.

Results: There were no significant differences in the umbilical artery pulsatility index (PI), resistance index $(\mathrm{RI})$, or systolic/diastolic ratio (S/D) between the PE and normal pregnancies. The spiral and uterine artery RI, PI, and SD ratios, however, were significantly higher in the PE group. There was no statistically significant difference in the mean microvessel density between the 2 groups.

Conclusion: The role of the placenta in the development of PE is unquestionable. Vascular pathologies and blood flow characteristics demonstrate significant differences and deteriorations compared with normal pregnancies. Further research is needed to further define the precise pathology.

\section{INTRODUCTION}

Preeclampsia (PE) is a significant cause of morbidity and mortality in pregnancy. ${ }^{[1]} \mathrm{PE}$ may lead to the death of the mother, and is one of the leading causes of preterm births and infant deaths. ${ }^{[2]}$ Even though it is one of the most significant and frightening conditions in pregnancy, the pathophysiology of PE has remained unclear. ${ }^{[3]}$ Symptoms of the condition are associated with the pregnancy itself and these symptoms resolve when the pregnancy ends. The presence of the placenta is mandatory for the occurrence of the disease. ${ }^{[4]}$ Preeclampsia is known as a placental development issue, with a structural problem in the spiral arteries of the placental bed, in particular. ${ }^{[5]}$

Doppler measurements of blood flow in maternal vessels are an important part of the assessment of perfusion in the fetomaternal unit. Fetal-maternal flow is a low-resistant, low-pressure, and high-flow system. Pathological blood flow curves of main uterine vessels are associated with intrauterine growth restriction or preeclampsia. In addition to maternal vessels, Doppler studies can be performed to measure blood flow in many vessels of fetal 
circulation; fetal hypoxia and the response of the fetus to hypoxia can be assessed. ${ }^{[6]}$

Unstable angiogenesis is one of the leading issues emphasized as a cause of preeclampsia. Angiogenesis may be affected by several factors, including growth factors, receptors, and disorders. ${ }^{[7]}$

Microvessel density (MVD) is a measure of the intensity of angiogenesis in tumors. Another issue emphasized and investigated in a study was a possible association between hypertension and progressive reduction in microvessel density in the placental bed. However, the results were not conclusive. ${ }^{[8]}$

Based on this knowledge, this study was an investigation of abnormal uteroplacental circulation resulting from endothelial damage associated with preeclampsia and abnormal placentation as assessed by Doppler ultrasound. In addition, an immunohistochemical analysis of the placental tissue and measurement of the microvessel density was conducted to assess placental angiogenesis.

\section{MATERIAL AND METHODS}

This prospective, controlled, study included 40 women (25 pregnant women with PE in the study group and I5 healthy pregnant women in the control group) who were 26 to 40 weeks pregnant and who attended the maternity outpatient clinics of our hospital. In this study, the umbilical artery, uterine arteries, and spiral arteries were examined with Doppler ultrasound and the results were recorded. The diagnosis was made based on a histological examination of placenta specimens in $10 \%$ buffered formaldehyde solution in women who would give birth within the next I week. Intergroup comparisons of microvessel counts in tissues obtained from the maternal side of the placenta were performed by the same pathologist who was blinded to the patient's diagnosis. Five patients were excluded from the study because the placenta could not be submitted to the pathology department on the same day or necrotic areas were predominant in placenta. Patients with chronic diseases, multiple pregnancies, gestational diabetes mellitus, type I and type 2 diabetes mellitus, chronic kidney disease, or intrauterine growth restriction (IUGR) were excluded. Thus, the study was continued with 23 pregnant women with PE and 12 healthy pregnant women. Approval for the study was granted by the ethics committee (Ethics Committee Decision No. 01 of August 7, 2008). Every study participant was informed about the study, underwent obstetric assessments, and a medical history was obtained. Each woman underwent an ultrasound examination to assess fetal growth.

Urinalysis was also performed on all participants to exclude a possible urinary infection and the women were included in the study if they had no symptoms of urinary infection. The diagnosis of PE was made based on the National High Blood Pressure Education Program Working Group on High Blood Pressure in Pregnancy (2000) criteria (arterial blood pressure $\geq 140 / 90 \mathrm{mmHg}$ and $\geq 1+$ g proteinuria in spot urine test). Blood pressure was measured in a sitting position after at least 10 minutes of rest, auscultatory measurement of systolic blood pressure was based on phase I Korotkoff sound and diastolic blood pressure was based on phase 5 Korotkoff sound. ${ }^{[9]}$

Blood pressure measurements were repeated 6 hours later if the subject's blood pressure was elevated. If the arterial blood pressure was found to be $\geq 140 / 90 \mathrm{mmHg}$ in the second measurement, then the subject was considered to have hypertension and was diagnosed with preeclampsia if I+ proteinuria was detected in a spot urine test.

The American College of Obstetricians and Gynecologists (ACOG) Practice Bulletin 2002 criteria were used to define mild and severe preeclampsia. ${ }^{[10]}$ Pregnant women who met at least I of these criteria (A systolic blood pressure of $160 \mathrm{mmHg}$ or higher, a diastolic blood pressure of $110 \mathrm{mmHg}$ or higher on 2 occasions at least 6 hours apart while the patient is on bed rest, proteinuria of $5 \mathrm{~g}$ or higher in a 24-hour urine specimen or $\geq 3+$ on 2 random spot urine sample collected at least 4 hours apart, oliguria of less than $500 \mathrm{~mL}$ in 24 hours, cerebral or visual disturbances, pulmonary edema or cyanosis, epigastric or right upper-quadrant pain, impaired liver function, thrombocytopenia, or intrauterine fetal growth delay) were diagnosed with severe preeclampsia.

The control group included healthy pregnant women matched for age, gravidity, and parity. Umbilical, uterine, and spiral artery flow measurements were performed using a Siemens Acuson Antares Ultrasound machine with color Doppler feature, equipped with a transabdominal 3.5-5 MHz Convex probe able to show real-time blood flow (Siemens Healthineers, GmbH, Erlangen, Germany).

Technique of measurement of umbilical artery blood flow: The ultrasound probe was placed over the abdomen of the mother. A free loop of the umbilical cord was visualized and the Doppler sampling window was set to include both the umbilical vein and artery. The pulsed Doppler probe was moved systematically until the characteristic umbilical arterial and venous blood flow velocity waveforms were obtained. The measurements were performed at this point using 3 similar waveforms and the results were recorded.

Technique of measurement of uterine artery blood flow: The mothers were placed on a flat examination table in the lateral decubitus position with a slightly elevated head. The ultrasound probe was placed over the lower lateral abdominal quadrant and was angled medially, the Doppler sampling window was set $\mathrm{I} \mathrm{cm}$ medially to the site where the uterine artery left the internal iliac artery 
and crossed the external iliac artery. The measurements were performed at this point using 3 similar waveforms and the results were recorded.

\section{Technique of measurement of spiral artery blood}

flow: The vascularization of the maternal decidua was visualized with color Doppler imaging. Low-resistance waveforms synchronized with the mother's pulses were systemically found, measured, and recorded.

Histological assessments: Pregnant women underwent Doppler ultrasound within I week before the birth date and the results were recorded. The entire placenta was submitted to the department of pathology in 10\% buffered formaldehyde and paraffin blocks were prepared from specimens of maternal side of the placenta by a single pathologist, avoiding predominantly necrotic areas. Selected paraffin sections of $4 \mu \mathrm{m}$ in thickness were immunohistochemically stained with CD34 (Clone:QBEnd/I0, dilution I/I00; Thermo Fisher Scientific, Inc., Waltham, MA, USA) and the number of microvessels was determined at 3 hot spots using an Olympus microscope (Tokyo, Japan) with $\times 10$ ocular and $\times 20$ objective by the same pathologist (Fig. Ia, b).

\section{Statistical analysis}

SPSS for Windows, Version 15.0 (SPSS, Inc., Chicago, IL, USA) was used to perform the statistical analysis of the data. A chi-square test was used to analyze categorical values. Descriptive data were presented as percentages, mean \pm standard deviations. Student's t-test was used for intergroup comparisons of parametric variables and the Mann-Whitney $U$ test was used for intergroup comparisons of non-parametric variables. One-way analysis of

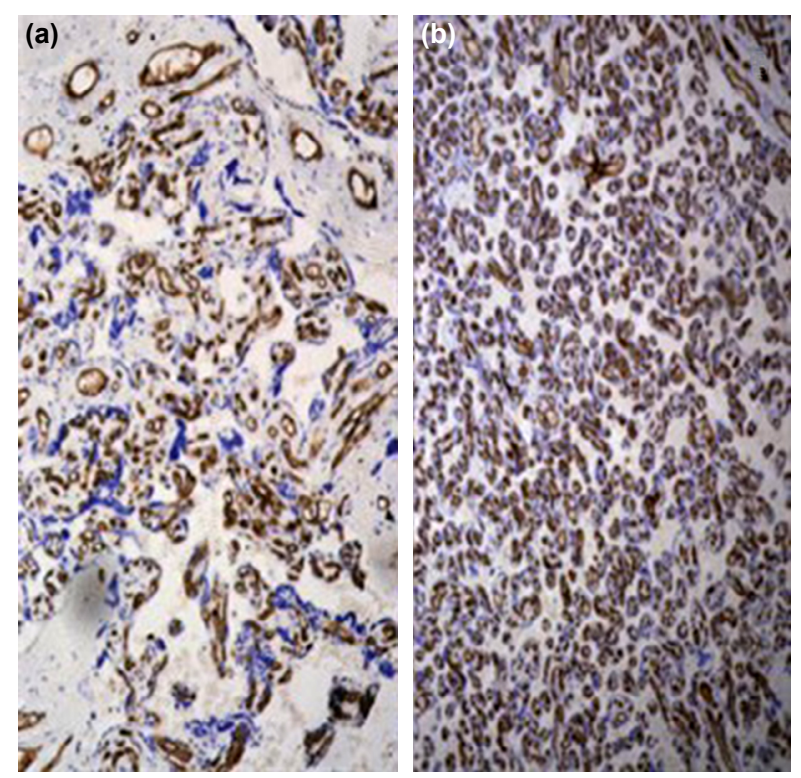

Figure 1. Evaluation of placental microvessel density in CD 34dyed areas. (a) less microvessel density, (b) greater microvessel density. variance was used for multiple group comparisons. A P value $<0.05$ was considered as statistically significant.

\section{RESULTS}

Twenty-three participants (65.7\%) were included in the Study Group and 12 (34.3\%) were included in the Control Group. Based on the ACOG preeclampsia criteria, 16 subjects $(45.7 \%)$ were diagnosed with mild PE and 7 (20.0\%) were diagnosed with severe PE in the Study Group. Statistical analyses of demographic characteristics did not reveal any significant differences in gravidity, parity, or age. The week of delivery was significantly earlier in the Study Group than in the Control Group ( $<<0.001$ ) (Table I).

No intergroup differences were found in the umbilical artery pulsatility index $(\mathrm{PI})$, resistance index (RI), or the systolicl diastolic ratio $(S / D)$, while there were statistically significant intergroup differences in uterine artery $\mathrm{PI}, \mathrm{RI}$, and $\mathrm{S} / \mathrm{D}$ as well as spiral artery $\mathrm{PI}, \mathrm{RI}$, and $\mathrm{S} / \mathrm{D}$, which were the parameters used in Doppler analyses to indirectly assess placental blood supply $(p=0.01)$. No statistically significant intergroup differences were found in MVD as assessed by immunohis-

Table I. Demographic parameters of the study groups

\begin{tabular}{lccc}
\hline & Preeclampsia & Control & p \\
\hline Age & $27.70 \pm 4.72$ & $27.83 \pm 3.43$ & 0.92 \\
Gravida & $1.91 \pm 0.90$ & $2.33 \pm 1.23$ & 0.25 \\
Parity & $0.73 \pm 0.86$ & $1.08 \pm 0.90$ & 0.27 \\
Pregnancy week & $33.30 \pm 2.98$ & $36.67 \pm 1.88$ & $<0.001$ \\
\hline
\end{tabular}

*All values are given as mean $\pm \mathrm{SD}$.

Table 2. Statistical analysis of Doppler findings and microvessel density

\begin{tabular}{lccc}
\hline & Preeclampsia & Control & p \\
\hline Umbilical artery PI & $1.17 \pm 0.32$ & $0.98 \pm 0.14$ & 0.61 \\
Umbilical artery RI & $0.67 \pm 0.11$ & $0.63 \pm 0.05$ & 0.19 \\
Umbilical artery S/D & $3.67 \pm 1.5 \mathrm{I}$ & $2.76 \pm 0.40$ & 0.05 \\
Uterine artery PI & $1.52 \pm 0.53$ & $0.95 \pm 0.30$ & 0.02 \\
Uterine artery RI & $0.67 \pm 0.09$ & $0.53 \pm 0.30$ & $<0.00 \mathrm{I}$ \\
Uterine artery S/D & $3.69 \pm 1.35$ & $2.21 \pm 0.39$ & 0.01 \\
Spiral artery PI & $0.63 \pm 0.13$ & $0.51 \pm 0.12$ & 0.01 \\
Spiral artery RI & $0.44 \pm 0.06$ & $0.38 \pm 0.07$ & 0.01 \\
Spiral artery S/D & $1.83 \pm 0.25$ & $1.63 \pm 0.18$ & 0.01 \\
Microvessel density & $131.04 \pm 31.20$ & $128.83 \pm 22.1$ & 0.82
\end{tabular}

*All values are given as mean \pm SD. PI: Pulsatility index; RI: Resistance index; S/D: Systolic/diastolic ratio. 
Table 3. Statistical analysis of microvessel density between mild preeclampsia, severe preeclampsia, and control groups

\begin{tabular}{lcccc}
\hline & Mild preeclampsia & Severe preeclampsia & Control & P \\
\hline Microvessel density & $130.56 \pm 30$ & $132.14 \pm 34$ & $128.83 \pm 22.1$ & 0.90 \\
\hline *All values are given as mean \pm SD. & & &
\end{tabular}

tochemical staining of placental vessels $(p=0.82)$ (Table 2$)$.

No statistically significant differences in MVD were found between the severe PE group and the control group when the groups were stratified as mild PE, severe PE, and controls $(p=0.90)$ (Table 3).

\section{DISCUSSION}

Doppler analyses revealed statistically significant intergroup differences in uterine artery $\mathrm{PI}, \mathrm{RI}$, and $\mathrm{S} / \mathrm{D}$ as well as in spiral artery PI, RI, and S/D ( $\mathrm{p}=0.0 \mathrm{I})$.

The increase in the diastolic integral of velocity waveforms of the uterine artery and its branches measured by Doppler ultrasound is a result of physiological alterations in spiral arteries. Spiral artery velocities decrease as the pregnancy progresses. As the pregnancy progresses, the resistance of the uterine arteries decreases and the diastolic flow increases, ${ }^{\left[{ }^{11}\right]}$ which are reflected in reduced $S / D$, $\mathrm{PI}$, and $\mathrm{RI}$ rates, and the diastolic notch disappears. A S/D rate greater than 2.6 and the presence of notching after the $26^{\text {th }}$ week of pregnancy have been considered pathological findings. ${ }^{[12]}$ Our study included fetuses older than 26 weeks of age, and the $\mathrm{PI}$ and $\mathrm{RI}$ in the uterine artery and spiral artery measured with Doppler ultrasound were higher in the PE group. The mean uterine artery S/D was $3.69 \pm 1.35$ in the PE group and a statistically significant difference was determined between the groups.

A number of Doppler studies of utero-placental circulation have been conducted to predict gestational hypertension and/or IUGR. Arcuate artery Doppler ultrasound studies conducted by Campbell et al. ${ }^{[13]}$ indicated that $12 \%$ of patients who were 16 to 18 weeks pregnant developed PE and IUGR was observed in $14 \%$. Hanretty et al. ${ }^{[14]}$ reported that the pregnancy outcomes were not affected by either abnormal or normal Doppler findings in a study of 291 pregnant women who were 26 to 30 weeks pregnant.

Irion et al. ${ }^{[5]}$ conducted a uterine artery Doppler ultrasound study of II59 nulliparous pregnant women at the 26th week of pregnancy and found an increased resistance rate in $13 \%(\mathrm{RI}>0.57)$. The sensitivity was $26 \%$ for $\mathrm{PE}$ and $29 \%$ for IUGR. In our study, a diastolic notch was observed in the uterine arteries of 15 pregnant women (65\%) who were already diagnosed with $\mathrm{PE}$ and the mean $\mathrm{RI}$ value in the $P E$ group and the healthy control group was $0.67 \pm 0.09$ and $0.53 \pm 0.06$, respectively. Increased uterine artery resistance in the preeclampsia group was consistent with the previous reports in the literature. ${ }^{[15]}$

Brosens et al. ${ }^{[16]}$ reported that physiological alterations had not occurred in the spiral arteries of the placental bed of biopsy specimens of pregnant women with preeclampsia.

Somunkıran et al. ${ }^{[17]}$ investigated associations between uterine artery Doppler findings and histological findings in biopsy specimens from placental beds in cases of IUGR, and the rates of inadequate trophoblastic invasion, acute atherosis, thrombosis, and luminal obliteration were found to be significantly higher. Extra-villous trophoblasts were also greater in those with pathological uterine artery Doppler findings. ${ }^{[17]}$

Madazli et al. ${ }^{[18]}$ observed insufficient trophoblastic invasion of spiral arteries. Elevated levels of trophoblasts were present; however, they did not invade the surrounding multi-layered vessels of interstitial tissues. Thrombosis and atheromatous plaques in thick-walled spiral arteries and in vessel lumens were observed in biopsy specimens of placental beds from patients with PE. In 25 normotensive subjects, 16 with mild $P E, 16$ with severe $P E$, and 3 with eclampsia, the rate of pathological findings detected in specimens from the placental bed was $0 \%, 40 \%, 69 \%$, and $100 \%$, respectively. The total number of spiral arteries in the placental bed has been estimated to be 100 to 200 , and considering that about 2 to 3 spiral arteries can be assessed in each biopsy specimen, it can be said that biopsy specimens may not reflect general vessel structure of the placental bed.

MVD assessment using CD34 has been a widely used method to assess tumor vascularity. Considering that the terminology of angiogenesis was first defined with regard to the placenta, we planned to use MVD evaluation with CD34 to assess placental angiogenesis in our study. There were no statistically significant differences between the severe $\mathrm{PE}$, mild $\mathrm{PE}$, and control groups in microvessel count, which suggested the impossibility of making a distinction between abnormal angiogenesis, angiogenesis, and pseudo-angiogenesis based on MVD.

In a study conducted by Coelho et al., ${ }^{[8]}$ microvessels were counted in biopsy specimens of the placental bed obtained from 34 pregnant women with $\mathrm{PE}$ and 26 normotensive women during a C-section and they found a statistically 
significant difference between the hypertensive and normotensive groups in MVD. They reported that vessel counts were lower in the myometrial segment compared with the decidual segment (48 vs 38 in the decidual segment and 36 vs 25 in the myometrial segment in the PE group and the control group, respectively). In the same study, IUGR was detected in 16 of 34 pregnant women with PE, which suggested that the differences in microvessel counts might originate in clinical placental insufficiency. However, the objective of our study was to assess microvessel count during preclinical periods when maternal hypertensive disease had no negative impact on the fetus yet. In our study, biopsy specimens were obtained from the maternal side of the placenta and the absence of any significant difference between the severe PE group and the healthy control group in placental microvessel count might have been the result of anatomical and physiological differences between the vascular structure of the placenta and that of the placental bed. The inclusion of subjects in a specific period of pregnancy when maternal hypertensive disease had no negative impact on the fetus and normal umbilical artery Doppler measurements might be the cause of the absence of any intergroup differences in MVD.

The placenta and the decidua may play important roles: a defective placenta during remodeling of the spiral arteries can release many factors, resulting in systemic endothelial dysfunction and PE. Moreover, the spiral arteries of patients with PE (approximately 40\%-60\%) undergo pathological changes but are unaffected by physiological remodeling during pregnancy. These changes could have affected our results. The case count in our study may also have influenced the findings. In the literature, different markers are used for angiogenesis. Vascular endothelial growth factor (VEGF), CD34, VEGF receptor3, and CD3 I proteins were principally used in various studies to show placental and endothelial cells and angiogenesis. CD34 is an endothelial cell marker and potential indicator of vascular differentiation, CD3I is a pan endothelial marker, and VEGF plays an important role in angiogenesis. ${ }^{[19]}$

A semi-quantitative, immunohistochemical assessment of angiogenesis was performed by Barut et al. ${ }^{[20]}$ using placental biopsy specimens from 55 cases of IUGR and 55 healthy pregnant women. A scale of 0 to $3+$ was used, with 0 representing no staining and $3+$ representing strong staining. Strong staining was observed in the IUGR group and weak staining was observed in the healthy pregnant group, and these findings were reported to be associated with placental insufficiency and fetal growth restriction, including increased proliferation in the connective tissue and villous capillaries related to growth factors such as VEGF and fibroblast growth factor induced by hypoxic stimulation of the placenta and abnormal vasculogenesis, angiogenesis, pseudo-vascularization, and IUGR. Placental bed biopsies and placental biopsies reflect abnormal Doppler waveforms of the uterine and umbilical arteries. Clinical outcomes are poorer and perinatal mortality occurs when both uterine artery Doppler and umbilical artery Doppler indicate impaired blood flow.

In the literature, we must talk about decidual vasculopathy (DV). Spiral arteries of patient with PE undergo pathological changes. These changes occur in the decidua, an important fetal-maternal interface, and are referred to as DV or acute atherosis. Several clinical studies have suggested a higher prevalence of preexisting hypertension in the PE group with DV than in PE patients without DV, but in our study, preexisting hypertension was an exclusion criterion. This may have had an effect on our results. Future studies should also include more participants.

\section{CONCLUSION}

In conclusion, the role of the placenta in the development of $P E$ is indisputable. $P E$ is associated with vascular pathologies and impaired blood supply, and the characteristics of blood supply differ significantly between pregnancies with $\mathrm{PE}$ and normal pregnancies. Additional studies are needed to further define and understand the pathology.

Ethics Committee Approval

Approved by the local ethics committee (Ethics Committee Decision No. 0 I of August 7, 2008).

Peer-review

Internally peer-reviewed.

Authorship Contributions

Concept: B.E., K.G.; Design: B.E., K.G., G.Y., O.A.; Data collection \&/or processing: B.E., G.Y., O.A.; Analysis and/ or interpretation: B.E., C.E., G.Y., O.A., M.C.T.; Literature search: B.E., Ö.S., M.C.T., E.E.Ş.; Writing: B.E., Ö.S., M.C.T., E.E.Ş.; Critical review: B.E., Ö.S., M.C.T., E.E.Ş.

Conflict of Interest

None declared.

\section{REFERENCES}

1. Wataganara T, Leetheeragul J, Pongprasobchai S, Sutantawibul A, Phatihattakorn C, Angsuwathana S. Prediction and prevention of pre-eclampsia in Asian subpopulation. J Obstet Gynaecol Res 2018;44:813-30. [CrossRef]

2. Quan LM, Xu QL, Zhang GQ, Wu LL, Xu H. An analysis of the risk factors of preeclampsia and prediction based on combined biochemical indexes. Kaohsiung J Med Sci 2018;34:109-12. [CrossRef]

3. Cornelius DC. Preeclampsia: From Inflammation to Immunoregulation. Clin Med Insights Blood Disord 2018;11:1179545X17752325.

4. Sircar M, Thadhani R, Karumanchi SA. Pathogenesis of preeclampsia. Curr Opin Nephrol Hypertens 2015;24:131-8. [CrossRef]

5. Martinez-Fierro ML, Hernández-Delgadillo GP, Flores-Morales V, Cardenas-Vargas E, Mercado-Reyes M, Rodriguez-Sanchez IP, et al. Current model systems for the study of preeclampsia Exp Biol Med 
(Maywood) 2018;243:576-85. [CrossRef]

6. Aksornphusitaphong A, Phupong V. Combination of serum histidine-rich glycoprotein and uterine artery Doppler to predict preeclampsia. Hypertens Res 2018;41:275-81. [CrossRef]

7. Kaufmann P, Mayhew TM, Charnock-Jones DS. Aspects of human fetoplacental vasculogenesis and angiogenesis. II. Changes during normal pregnancy. Placenta 2004;25:114-26. [CrossRef]

8. Coelho TM, Sass N, Camano L, Moron AF, Mattar R, Stávale JN, et al. Microvessel density in the placental bed among preeclampsia patients. Sao Paulo Med J 2006;124:96-100. [CrossRef]

9. Report of the National High Blood Pressure Education Program Working Group on High Blood Pressure in Pregnancy. Am J Obstet Gynecol 2000;183:S1-22. [CrossRef]

10. ACOG Committee on Practice Bulletins-Obstetrics. ACOG practice bulletin. Diagnosis and management of preeclampsia and eclampsia. Number 33, January 2002. Obstet Gynecol 2002;99:159-67.

11. Campbell S, Diaz-Recasens J, Griffin DR, Cohen-Overbeek TE, Pearce JM, Willson K, et al. New doppler technique for assessing uteroplacental blood flow. Lancet 1983;1:675-7. [CrossRef]

12. Ferrazzi E, Bulfamante G, Mezzopane R, Barbera A, Ghidini A, Pardi G. Uterine Doppler velocimetry and placental hypoxic-ischemic lesion in pregnancies with fetal intrauterine growth restriction. Placenta 1999;20:389-94. [CrossRef]

13. Campbell S, Pearce JM, Hackett G, Cohen-Overbeek T, Hernandez C. Qualitative assessment of uteroplacental blood flow: early screen- ing test for high-risk pregnancies. Obstet Gynecol 1986;68:649-53.

14. Hanretty KP, Primrose MH, Neilson JP, Whittle MJ. Pregnancy screening by Doppler uteroplacental and umbilical artery waveforms. Br J Obstet Gynaecol 1989;96:1163-7. [CrossRef]

15. Irion O, Massé J, Forest JC, Moutquin JM. Prediction of pre-eclampsia, low birthweight for gestation and prematurity by uterine artery blood flow velocity waveforms analysis in low risk nulliparous women. Br J Obstet Gynaecol 1998;105:422-9. [CrossRef]

16. Brosens IA, Robertson WB, Dixon HG. The role of the spiral arteries in the pathogenesis of preeclampsia. Obstet Gynecol Annu 1972;1:177-91.

17. Somunkıran A, Madazlı R, Calay Z, İlvan Ş, Körbeyli B, Şimşek $\mathrm{Y}$. The comparison of uterine artery Doppler velocimetry with the histopathology of the placental bed [Article in Turkish]. Cerrahpaşa J Med 2002;33:231-5.

18. Madazli R, Budak E, Calay Z, Aksu MF. Correlation between placental bed biopsy findings, vascular cell adhesion molecule and fibronectin levels in pre-eclampsia. BJOG 2000;107:514-8. [CrossRef]

19. Liu H, Li Y, Zhang J, Rao M, Liang H, Liu G. The defect of both angiogenesis and lymphangiogenesis is involved in preeclampsia. $\mathrm{Pla}$ centa 2015;36:279-86. [CrossRef]

20. Barut F, Barut A, Gun BD, Kandemir NO, Harma MI, Harma M, et al. Intrauterine growth restriction and placental angiogenesis. Diagn Pathol 2010;5:24. [CrossRef]

\section{Preeklamptik Gebelerde Spiral Arter Doppleri ve Plasental Mikrodamar Yoğunluğunun Immünhistokimyasal İncelenmesi}

Amaç: Preeklamptik ve normal gebelerde Doppler parametreleri ve plasental mikrodamar yoğunluğunun immünohistokimyasal olarak araştırılması amaçlandı.

Gereç ve Yöntem: Hastanemizde 2008 ile 2010 yılları arasında takip edilen ve doğumu gerçekleştirilen 23 preeklamptik ve 12 normal gebenin umblikal, uterin ve spiral arter renkli Doppler ölçümleri yapıldı ve kaydedildi. Plasental örnekleri doğum esnasında alındı. Plasental örnekler, immünhistokimyasal teknikle değerlendirildi. Spiral arterlerin mikrodamar yoğunluğu immünohistokimyasal olarak plasental dokuda CD34 antikor kullanılarak sayıldı. Mikrodamar yoğunluğu CD34'ün en yoğun olduğu üç damarsal alanda değerlendirildi.

Bulgular: Preeklamptik ve normal gebelerin umblikal arter PI, RI ve SD oranlarına göre farklılık bulunmadı. Buna rağmen; preeklamptik grupta spiral ve uterin arter RI, PI ve SD oranları anlamlı olarak yüksekti. Her iki grup arasında ortalama mikrodamar yoğunluğu arasında istatistiksel olarak anlamlı fark bulunmadı.

Sonuç: Sonuç olarak, plasentanın preeklampsi gelişimindeki rolü tartışılmazdır. Vasküler patolojiler ve kanlanma özellikleri normal gebelere oranla anlamlı derecede farklılıklar ve bozulmalar göstermektedir. Nihai patolojiye sebep olan bu değişikliklerin tam olarak belirlenebilmesi için ve düzeltilebilmesi için daha ileri araştırmalara ihtiyaç vardır.

Anahtar Sözcükler: Antijenler CD34; mikrodamarlar; pre-eklampsi; ultrasonografi Doppler. 